\title{
Nutritional value and coagulation properties of milk from local cow breeds, including the selected macro- and micronutrients and trace elements
}

\author{
Anna Teter, Monika Kędzierska-Matysek*, \\ Joanna Barłowska, Jolanta Król, Aneta Brodziak
}

University of Life Sciences, Institute of Quality Assessment and Processing of Animal Products,

Akademicka 13, 20-950 Lublin, Poland

*Corresponding author: monika.matysek@up.lublin.pl

\section{Abstract}

The aim of the study was to assess the nutritional value of milk based on its chemical composition and content of selected minerals and to determine the coagulation properties of raw milk from native Polish breeds, i.e. the Polish Red and the White-backed, as well as locally raised Simmental cows, taking into account the production season. The research material consisted of 418 milk samples taken during the spring/summer season (April to September) and autumn/winter season (October to March). The following parameters were determined in the samples: chemical composition, energetic value, coagulation properties (RCT - rennet clotting time, $A_{30}$ - curd firmness, $\mathrm{K}_{20}$ - curd firming time), cheese yield, and content of $\mathrm{K}, \mathrm{Na}, \mathrm{Ca}, \mathrm{Mg}, \mathrm{Zn}, \mathrm{Fe}, \mathrm{Mn}, \mathrm{Cu}, \mathrm{Ni}$ and $\mathrm{Co}$. The percentage of the daily allowance for $\mathrm{Ca}$ and $\mathrm{Mg}$ in children, adolescents and adults from $250 \mathrm{~mL}$ of milk was determined. The milk of Polish Red cows had the highest concentration of basic nutrients ( $1 \mathrm{~kg}$ of milk provided $823.98 \mathrm{kcal}$ ) and the best coagulation parameters (the shortest clotting time $(16: 09$ min, $p \leq 0.01)$ and firmest curd $(30.74$ $\mathrm{mm}$ ). This milk had a more beneficial nutritional profile, as it contained the highest percentage of the recommended daily allowances of $\mathrm{Ca}$ and $\mathrm{Mg}$ among all groups. The raw milk obtained in the pasture season showed more favourable coagulation properties. The content of minerals in milk is not clearly determined by the cow breed or the season. It is probably due to the higher levels of these nutrients in the feed, which in turn results from their content in the soil and the degree of fertilization.

Key words: local breeds, minerals, production season, coagulation properties, nutritional value 


\section{Introduction}

Cow milk is a valuable source of many minerals, which are present in amounts and proportions that allow their optimal absorption from the gastrointestinal tract. Milk and dairy products are an excellent source of easily digestible $\mathrm{Ca}$, as well as P, Na, $\mathrm{K}, \mathrm{Cl}, \mathrm{I}$ and $\mathrm{Mg}$. They also contain a small amount of Fe (Manuelian et al., 2018b).

Both, the chemical composition of milk and it's content of minerals are variable and depend on many factors, including the breed of cows or their diet, which clearly differs on traditional and intensive farms. The content of minerals in milk depends largely on their content in feed, and this in turn depends on the soil conditions and the level of fertilization (Halagarda et al., 2018). The vast majority of milk produced in Poland comes from large-scale farms raising high-production Holstein-Friesian cows, fed in the same manner year round in a TMR (Total Mixed Ration) or PMR (Partially Mixed Ration) system. Research results indicate that milk produced in such a system has high content of basic nutrients, but is less suitable for cheese production (Król et al., 2010b; Toledo et al., 2002) and has a lower content of biologically active compounds ( $\mathrm{Ga}$ bryszuk et al., 2008; Brodziak et al., 2018) than raw milk from cows whose diet is based mainly on green forage. Feeding strategies based on pasture grazing are mainly used by dairy farmers raising dual-purpose cows, such as the Simmental breed, or native breeds such as Polish Red or White-backed. Cows of these breeds have many unique features (e.g. outstanding longevity, high fertility and good health), which enable them to survive in changing environmental conditions. These properties are genetically determined, which indicates that native breeds have a unique gene pool that distinguishes them from high-production breeds (Litwińczuk et al., 2012). Milk obtained from these cows has a higher nutritional value and is more suitable for processing, but due to the lower productivity of these animals, they are much less profitable to raise than breeds used in intensive farming systems (Gandini et al., 2007; Król et al., 2010b).

The aim of the study was to assess the nutritional value of milk based on its chemical composition and the content of selected minerals; as well as to determine the coagulation properties of raw milk from native Polish breeds, i.e. Polish Red and White-backed, and locally raised Simmental cows, taking into account the production season.

\section{Materials and methods}

\section{Milk samples}

The research material consisted of 418 milk samples taken from cows of two native breeds, Polish Red (RP, $n=114$ ) and White-backed (WB, $n=148$ ), as well as locally raised Simmental cows (SM, $n=156$ ). Milk samples were collected individually from cows twice a year during the test-day milking, i.e. once in the spring/summer season (April to September, $\mathrm{n}=$ 219; RP, $n=60 ; W B, n=78 ; S M, n=81$ ) and once in the autumn/winter season (October to March, $n=199$; $R P, n=54 ; W B, n=70 ; S M, n=75)$. The study included 18 farms ( 6 for each breed) that met the health requirements for raw milk production and hygiene standards, in accordance with Commission Regulation (EC) no. 1662/2006 laying down specific hygiene rules for food of animal origin. Cows were in their second to fifth lactation, between days 90 and 230 of lactation. The daily yield of the Polish Red cows was $12.71 \mathrm{~kg}$ (13.80 kg in the spring/summer and $11.5 \mathrm{~kg}$ in the autumn/winter season), for White-backed cows it was $14.52 \mathrm{~kg}$ (15.94 kg in the spring/summer and 12.93 $\mathrm{kg}$ in the autumn/winter season), and for Simmental $18.31 \mathrm{~kg}(21.06 \mathrm{~kg}$ in the spring/summer and 15.34 $\mathrm{kg}$ in the autumn/winter season). The cows were kept on family farms located in the Low Beskid Mountains (Polish Red), Bieszczady Mountains (Simmental) and the Lublin region (White-backed). A direct-to-can or pipeline milking system was used on all farms. The diet was based mainly on the on-farm feed. In the autumn/winter season, the diet was based on haylage and hay, and in the spring and summer the cows were grazed on pastures. The feed ration in both seasons was supplemented with the on-farm cereal meal. The feed was given manually twice a day after milking.

\section{Analytical procedures}

The percentage content of fat, protein, lactose and dry matter was determined in the milk samples using the Bentley 150, Infrared Milk Analyzer 
(Bentley Instruments, Inc., Minnesota, USA), which measures the energy absorption at specific wavelengths in the mid-infrared (MIR) region. Casein content was determined according to the AOAC method (2000). To eliminate milk samples from cows with udder inflammation, the somatic cell count was determined using the Somacount 150 (Bentley Instruments, Inc., Minnesota, USA).

The energetic value of $1 \mathrm{~kg}$ of milk ( $\mathrm{kcal} / \mathrm{kg}$ ) was determined using the physiological gross energy factors according to Rubner (Pijanowski et al., 2000):

$1 \mathrm{~kg}$ milk $(\mathrm{kcal})=\{[\%$ protein $\times 10](\mathrm{g}) \times$ density $(\mathrm{g} / \mathrm{mL}) \times 4.1(\mathrm{~kJ})\}+\{[\%$ fat $\times 10)](\mathrm{g}) \times$ density $(\mathrm{g} /$ $\mathrm{mL}) \times 9.3(\mathrm{kJJ})\}+\{[\%$ lactose $\times 10](\mathrm{g}) \times$ density $(\mathrm{g} /$ $\mathrm{mL}) \times 4.1(\mathrm{~kJ})\}$

The coagulation properties of milk (RCT - rennet clotting time, $A_{30}$ - curd firmness 30 minutes from the addition of the clotting enzyme, and $\mathrm{K}_{20}$ - the time at which the gel attains a specific firmness of $20 \mathrm{~mm}$ ) were determined with a Lactodynamograph (Foss, Italy). A $200 \mu \mathrm{L}$ volume of rennet solution was added to $10 \mathrm{~mL}$ of milk heated to $35^{\circ} \mathrm{C}$ (Naturen Plus 215, Hansen, Italy; 0.0513 IMCU/milk mL).

Cheese yield (the amount of cheese produced from $100 \mathrm{~kg}$ of milk) was estimated according to the formula of van Slyke (Melilli et al., 2002):

Cheese yield $(C Y)=[(0.93 \mathrm{G}+\mathrm{C}-0.1) \cdot 1.09 \cdot 100] /$ (100 - U)

where: G - milk fat (\%); C - casein (\%); U - moisture in cheese (\%); 1.09 - constant taking into account the effect of salt and other solids; 0.1 - estimated casein loss. The average water content in the cheese was assumed to be $59.5 \%$ (semi-hard cheese).

The content of selected elements, i.e. $\mathrm{K}, \mathrm{Na}$, $\mathrm{Ca}, \mathrm{Mg}, \mathrm{Zn}$, and $\mathrm{Fe}$, was determined by the atomic absorption spectrometry with air-acetylene flame atomization using a Varian AA240FS spectrophotometer (Fast Sequential Atomic Absorption Spectrometer). Other microelements ( $\mathrm{Mn}, \mathrm{Cu}, \mathrm{Ni}$ and Co) were determined in a graphite furnace with Zeeman background correction (in an argon atmosphere) with a Varian AA240Z spectrometer with a GTA-120 graphite tube atomizer. A mixture of 65\% nitric acid and $30 \%$ hydrochloric acid (SUPRAPUR) was poured over weighed samples of milk, followed by digestion in a MAREM 5 Xpress microwave oven (CEM Corporation, Matthews, NC, USA). To eliminate interference, the samples for determination of $\mathrm{K}, \mathrm{Na}, \mathrm{Ca}$ and $\mathrm{Mg}$ were diluted with
Schinkel correction buffer $\left(10 \mathrm{~g} \mathrm{~L}^{-1} \mathrm{CsCl}+100 \mathrm{~g} \mathrm{~L}^{-1}\right.$ La). Along with the analytical samples, blank samples and certified reference material (ERM-BD151 skimmed milk powder) were tested in the same way. All measurements were made in triplicate.

The percentage of the RDA (recommended dietary allowance) for Ca and $\mathrm{Mg}$ contained in $250 \mathrm{~mL}$ of milk was determined for the Polish population according to nutrition standards developed by the Food and Nutrition Institute in Warsaw. The following population groups were distinguished: children, boys, girls, men and women (NFNI, 2017). Ca and $\mathrm{Mg}$ were selected for calculations due to the frequent occurrence of deficiencies of these elements in the diet, even in developed countries.

\section{Statistical analysis}

The results were analysed by analysis of variance using Statistica ver. 13 software (Dell, 2016), taking into account the cow breed and production season as sources of variation. Significance of differences between means was determined by the Tukey test at $p \leq 0.05$ and $p \leq 0.01$. The Pearson correlation coefficients were calculated between the content of minerals and proximate chemical composition and the rennet coagulation parameters. The significance of the correlations was determined at $p \leq 0.05, p \leq 0.01$ and $p \leq 0.001$.

\section{Results and discussion}

The results presented in Table 1 confirm that both, the cow breed and the production season significantly determined the nutritional value of milk expressed by the levels of its main constituents, i.e. fat, protein and lactose. The highest concentration of the dry matter constituents was found in milk obtained from Polish Red cows. It was a significantly $(p \leq 0.01)$ more valuable source of fat, protein (including casein) and lactose $(p \leq 0.05)$ comparing to milk from White-backed and Simmental cows, and $1 \mathrm{~kg}$ of milk provided $823.98 \mathrm{kcal}$. The content of these nutrients and the energy value of the milk of White-backed and Simmental cows were similar (Table 1). Similar relationships have been shown by Litwińczuk et al. (2012) and Matwijczuk et al. (2015). 
TABLE 1. Energetic value, proximate chemical composition and coagulation parameters of milk in relation to the production season $(\overline{\mathrm{x}} \pm \mathrm{SD})$

\begin{tabular}{|c|c|c|c|c|c|c|c|c|c|}
\hline \multirow{2}{*}{$\begin{array}{l}\text { Breed } \\
\text { Season }\end{array}$} & \multicolumn{3}{|c|}{ White-backed } & \multicolumn{3}{|c|}{ Polish Red } & \multicolumn{3}{|c|}{ Simmental } \\
\hline & $\begin{array}{l}\text { Spring/ } \\
\text { summer }\end{array}$ & $\begin{array}{l}\text { Autumn/ } \\
\text { winter }\end{array}$ & $\begin{array}{l}\text { Overall mean } \\
\text { for breed }\end{array}$ & $\begin{array}{l}\text { Spring / } \\
\text { summer }\end{array}$ & $\begin{array}{l}\text { Autumn / } \\
\text { winter }\end{array}$ & $\begin{array}{l}\text { Overall mean } \\
\text { for breed }\end{array}$ & $\begin{array}{l}\text { Spring / } \\
\text { summer }\end{array}$ & $\begin{array}{l}\text { Autumn/ } \\
\text { winter }\end{array}$ & $\begin{array}{l}\text { Overall mean } \\
\text { for breed }\end{array}$ \\
\hline $\begin{array}{l}\text { Energetic } \\
\text { value } \\
\text { (kcal/kg) }\end{array}$ & $\begin{array}{l}714.96 \pm \\
107.50\end{array}$ & $\begin{array}{l}741.02 \pm \\
119.02\end{array}$ & $\begin{array}{l}728.45^{x} \pm \\
113.78\end{array}$ & $\begin{array}{l}780.94 \pm \\
73.84\end{array}$ & $\begin{array}{l}841.52 \pm \\
105.46\end{array}$ & $\begin{array}{l}823.98^{\curlyvee} \pm \\
100.32\end{array}$ & $\begin{array}{l}703.32 \pm \\
88.70\end{array}$ & $\begin{array}{l}737.47 \pm \\
69.67\end{array}$ & $\begin{array}{l}723.02^{x_{ \pm}} \\
79.31\end{array}$ \\
\hline $\begin{array}{l}\text { Fat } \\
\text { (g/100 g) }\end{array}$ & $\begin{array}{l}3.95 \pm \\
1.05\end{array}$ & $\begin{array}{l}4.07 \pm \\
1.06\end{array}$ & $\begin{array}{l}4.01 \pm \\
1.05\end{array}$ & $\begin{array}{l}4.49 \pm \\
0.7\end{array}$ & $\begin{array}{l}5.08 \pm \\
1.04\end{array}$ & $\begin{array}{l}4.91 \pm \\
0.98\end{array}$ & $\begin{array}{l}3.74^{\mathrm{A}} \pm \\
0.71\end{array}$ & $\begin{array}{l}4.21^{\mathrm{B}} \pm \\
0.69\end{array}$ & $\begin{array}{l}3.97 \pm \\
0.73\end{array}$ \\
\hline $\begin{array}{l}\text { Protein } \\
\text { (g/100 g) }\end{array}$ & $\begin{array}{l}3.18 \pm \\
0.43\end{array}$ & $\begin{array}{l}3.57 \pm \\
0.53\end{array}$ & $\begin{array}{l}3.38^{\curlyvee} \pm \\
0.52\end{array}$ & $\begin{array}{l}3.25 \pm \\
0.38\end{array}$ & $\begin{array}{l}3.55 \pm \\
0.49\end{array}$ & $\begin{array}{l}3.41^{\gamma} \pm \\
0.48\end{array}$ & $\begin{array}{l}3.32 \pm \\
0.17\end{array}$ & $\begin{array}{l}3.34 \pm \\
0.35\end{array}$ & $\begin{array}{l}3.33^{x} \pm \\
0.4\end{array}$ \\
\hline $\begin{array}{l}\text { Casein } \\
\text { (g/100 g) }\end{array}$ & $\begin{array}{l}2.49 \pm \\
0.37\end{array}$ & $\begin{array}{l}2.75 \pm \\
0.38\end{array}$ & $\begin{array}{l}2.63^{x} \pm \\
1.12\end{array}$ & $\begin{array}{l}2.59 \pm \\
0.45\end{array}$ & $\begin{array}{l}2.80 \pm \\
0.35\end{array}$ & $\begin{array}{l}2.71^{Y} \pm \\
0.39\end{array}$ & $\begin{array}{l}2.57 \pm \\
0.37\end{array}$ & $\begin{array}{l}2.61 \pm \\
0.34\end{array}$ & $\begin{array}{l}2.58^{x} \pm \\
0.36\end{array}$ \\
\hline $\begin{array}{l}\text { Lactose } \\
\text { (g/100 g) }\end{array}$ & $\begin{array}{l}4.82 \pm \\
0.27\end{array}$ & $\begin{array}{l}4.77 \pm \\
0.35\end{array}$ & $\begin{array}{l}4.80^{x y} \pm \\
0.31\end{array}$ & $\begin{array}{l}4.78 \pm \\
0.18\end{array}$ & $\begin{array}{l}4.86 \pm \\
0.20\end{array}$ & $\begin{array}{l}4.83^{y} \pm \\
0.22\end{array}$ & $\begin{array}{l}4.89 \pm \\
0.33\end{array}$ & $\begin{array}{l}4.61 \pm \\
0.30\end{array}$ & $\begin{array}{l}4.73^{x} \pm \\
0.34\end{array}$ \\
\hline $\begin{array}{l}\text { Dry matter } \\
\text { (g/100 g) }\end{array}$ & $\begin{array}{l}12.65^{\mathrm{A}} \pm \\
1.24\end{array}$ & $\begin{array}{l}13.11^{\mathrm{B}} \pm \\
1.52\end{array}$ & $\begin{array}{l}12.89^{\mathrm{x}} \pm \\
1.4\end{array}$ & $\begin{array}{l}13.22 \pm \\
0.89\end{array}$ & $\begin{array}{l}14.20 \pm \\
1.27\end{array}$ & $\begin{array}{l}13.74^{\gamma} \pm \\
1.2\end{array}$ & $\begin{array}{l}12.65 \pm \\
1.23\end{array}$ & $\begin{array}{l}12.86 \pm \\
0.82\end{array}$ & $\begin{array}{l}12.75^{\mathrm{x}} \pm \\
1.01\end{array}$ \\
\hline $\begin{array}{l}\text { RCT } \\
(\min )\end{array}$ & $\begin{array}{l}18: 31 \pm \\
4: 45\end{array}$ & $\begin{array}{l}19: 55 \pm \\
4: 38\end{array}$ & $\begin{array}{l}19: 14^{z} \pm \\
4: 42\end{array}$ & $\begin{array}{l}15: 27 \pm \\
5: 11\end{array}$ & $\begin{array}{l}16: 39 \pm \\
3: 53\end{array}$ & $\begin{array}{l}16: 09^{x} \pm \\
5: 49\end{array}$ & $\begin{array}{l}17: 00 \pm \\
4: 54\end{array}$ & $\begin{array}{l}17: 29 \pm \\
5: 56\end{array}$ & $\begin{array}{l}17: 15^{\gamma} \pm \\
5: 21\end{array}$ \\
\hline $\begin{array}{l}A_{30} \\
(\mathrm{~mm})\end{array}$ & $\begin{array}{l}24.08 \pm \\
10.09\end{array}$ & $\begin{array}{l}24.65 \pm \\
11.74\end{array}$ & $\begin{array}{l}24.37 \pm \\
10.86\end{array}$ & $\begin{array}{l}31.87 \pm \\
6.82\end{array}$ & $\begin{array}{l}29.68 \pm \\
7.41\end{array}$ & $\begin{array}{l}30.74 \pm \\
7.13\end{array}$ & $\begin{array}{l}24.41 \pm \\
8.44\end{array}$ & $\begin{array}{l}19.56 \pm \\
6.82\end{array}$ & $\begin{array}{l}21.78 \pm \\
7.91\end{array}$ \\
\hline $\begin{array}{l}\mathrm{K}_{20} \\
\text { (min) }\end{array}$ & 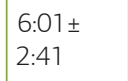 & $\begin{array}{l}5: 15 \pm \\
2: 23\end{array}$ & $\begin{array}{l}5: 38 \pm \\
2: 32\end{array}$ & $\begin{array}{l}4: 27 \pm \\
1: 48\end{array}$ & $\begin{array}{l}5: 19 \pm \\
1: 37\end{array}$ & $\begin{array}{l}4: 38 \pm \\
2: 05\end{array}$ & $\begin{array}{l}7: 14 \pm \\
3: 48\end{array}$ & 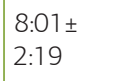 & $\begin{array}{l}7: 35 \pm \\
3: 19\end{array}$ \\
\hline $\begin{array}{l}\text { Cheese yield } \\
\text { (kg/100 kg) }\end{array}$ & $\begin{array}{l}16.32 \pm \\
2.64\end{array}$ & $\begin{array}{l}17.32 \pm \\
2.11\end{array}$ & $\begin{array}{l}16.81^{x_{ \pm}} \\
2.43\end{array}$ & $\begin{array}{l}17.94 \pm \\
2.74\end{array}$ & $\begin{array}{l}19.98 \pm \\
2.57\end{array}$ & $\begin{array}{l}18.93^{Y} \pm \\
1.43\end{array}$ & $\begin{array}{l}16.00 \pm \\
1.77\end{array}$ & $\begin{array}{l}17.29 \pm \\
1.73\end{array}$ & $\begin{array}{l}16.61^{x_{ \pm}} \\
1.83\end{array}$ \\
\hline
\end{tabular}

RCT - rennet coagulation time; $A_{30}$ - curd firmness 30 min after rennet addition; $\mathrm{K}_{20}$ - curd-firming time;

$a, b$ - significant differences between seasons within a breed at $p \leq 0.05 ; A, B$ - significant differences at $p \leq 0.01$

$X, y$ - significant differences between breeds at $p \leq 0.05 ; X, Y$ - significant differences at $p \leq 0.01$

TABLE 2. Results of a two-way analysis of variance for milk parameters, taking into account the effect of the breed and the production season

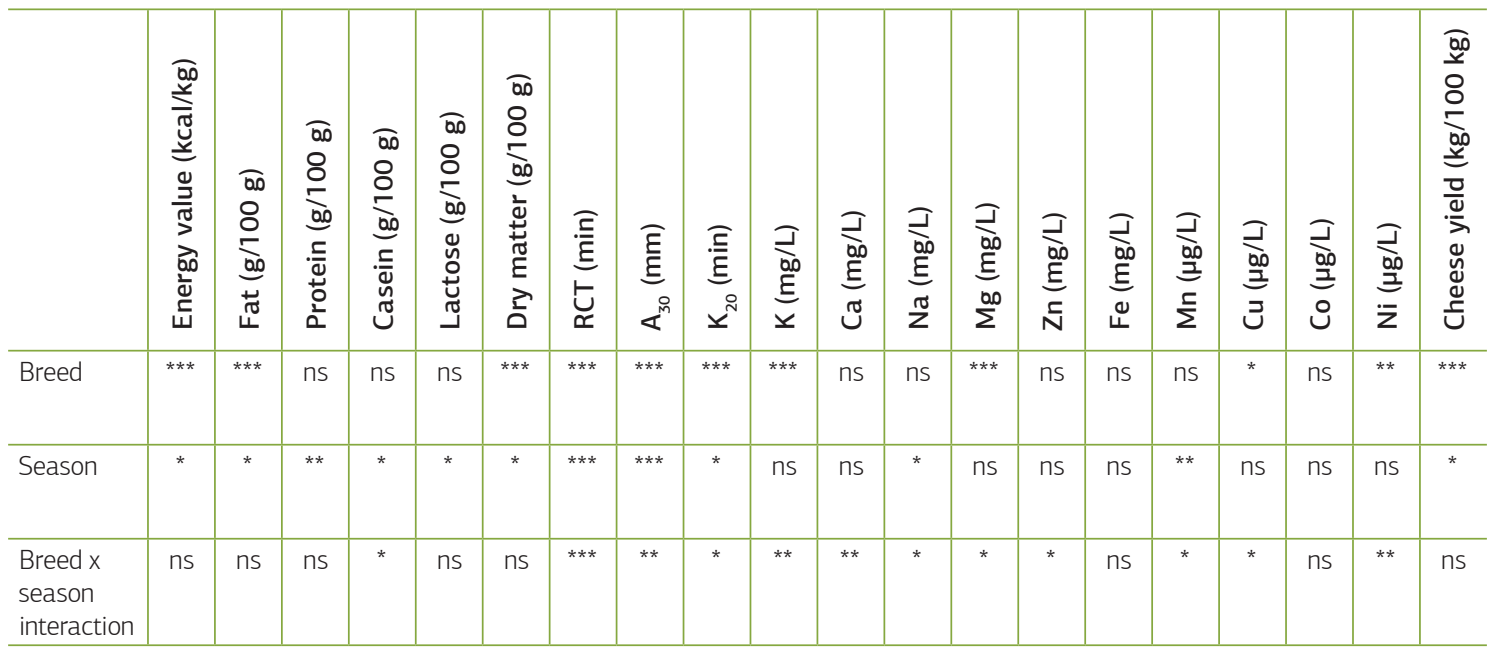

Effect of factor: ${ }^{*}-p \leq 0.05 ;{ }^{* *}-p \leq 0.01 ;{ }^{* * *}-p \leq 0,001$; ns - not significant 
Analysis of the effect of the season on the chemical composition of milk showed that the raw milk obtained in the autumn/winter season had higher content of dry matter components and caloric value than in spring/summer season. Milk of the Polish Red and Simmental cows grazing in the pasture contained about 0.5 p.p. less fat than in the autumn/winter season. The milk of White-backed cows had similar fat content irrespective of the season. Statistically significant differences were found for protein content, including casein. Milk from cows of native breeds in the spring/summer season contained significantly $(p \leq 0.01)$ less protein than in the autumn/winter season, including casein. Analysis of variance (Table 2 ) indicated that the breed significantly affected only the fat and dry matter content in the milk $(p \leq 0.001)$, while the season significantly influenced the content of protein $(p \leq 0.01)$, fat, lactose and dry matter $(p \leq 0.05)$. Analysis of the simultaneous impact of the breed and the production season revealed significant interactions for casein content $(p \leq 0.05)$.

The more favourable chemical composition of milk in the autumn/winter season is also supported by the research of other authors (Chládek et al., 2011; Brodziak et al., 2012; Bittante et al., 2015; Radkowska and Radkowski, 2016). In feeding dairy cows, it is very important to meet the demand for nutrients in relation to the animals' production potential. This is one of the key factors determining the quantity and composition of milk as well. According to Bohdanowicz-Zazula et al. (2003), traditional feeding in the summer results in lower protein content in milk due to protein and energy deficiencies, resulting in part from lower feed intake caused by high temperatures.

A key parameter determining the suitability of milk for cheese production is the rennet clotting time. Milk that does not coagulate after 30 minutes from the addition of rennet should not be used for cheese making. According to Zannoni and Annibaldi (1981), the optimal clotting time for milk intended for cheese making should be 11-18 min, and the resulting curd should reach a firmness of $20-40 \mathrm{~mm}$. The milk of cows of all breeds used in the study had good coagulation properties. The clotting parameters of the milk of Polish Red cows were the most favourable, with the shortest clotting time (16:09 min, $p \leq 0.01)$, the firmest curd (30.74 $\mathrm{mm}$ ) and the shortest curd firming time (4:38 min). The milk of the White-backed cows had the longest clotting time (19:14 min), while the curd obtained from the milk of Simmental cows had the longest firming time $(7: 35 \mathrm{~min})$. The milk obtained in the spring/summer (irrespective of cow breed) coagulated faster, and the resulting curd was firmer than in autumn/winter (except for the milk of Whitebacked cows). The differences, however, were not confirmed statistically. Analysis of variance (Table 2) indicated that the breed significantly affected all milk coagulation parameters and the cheese yield $(p \leq 0.001)$, and that the season significantly influenced RCT and $A_{30}(p \leq 0.001)$ as well as $K_{20}$ and $C Y$ $(p \leq 0.05)$. Analysis of the simultaneous effect of the breed and the season revealed significant interactions for coagulation parameters (Table 2).

The results of numerous studies clearly indicate that the milk of native breeds is a valuable raw material for cheese production. Bittante et al. (2012) analysed the milk coagulation properties of different cow breeds and found that local breeds (Rendena, Modicana, and Grey Alpine) had better milk parameters than high-production breeds with a global range (Holstein-Friesian, Montbéliarde, and Ayrshire). Similar results have been obtained by Kubarsepp et al. (2005), who assessed the milk coagulation parameters of cows of native Estonian breeds and Holstein-Friesians. Barłowska et al. (2012) reported more favourable coagulation properties for milk obtained in the summer than in winter season (irrespective of the housing system), similarly to Chládek et al. (2011). Bittante et al. (2015) showed a significantly shorter clotting time for milk obtained from April to September than from October to March ( $p \leq 0.01$ ), while curd firmness and curd firming time were similar irrespective of the production season. Beux et al. (2018) studied the coagulation properties of the milk of Italian Holstein-Friesians and reported that as many as $56.6 \%$ of milk samples collected in the summer were not coagulated by rennet (in autumn, 20.9\% of samples did not clot). Clotting time and curd firmness were most favourable for milk collected in autumn. The authors explain the high percentage of non-coagulated milk samples in the summer by the susceptibility of Holstein-Friesian cows to heat stress. According to Espinoza et al. (2009), selection of cattle for high productivity increases 
their sensitivity of to heat stress. In a comparison of Holstein and Jersey cows and the local Chinampo breed, the authors found that the native breed best tolerated high temperatures. Miranda and Freitas (2009) have reported that the critical temperature (above which cow productivity is reduced) is $24-26{ }^{\circ} \mathrm{C}$ for Holsteins and $>29.5^{\circ} \mathrm{C}$ for Brown Swiss.

The cheese yield from a given volume of milk is an important indicator in the economic evaluation of cheese production. It depends on many factors, including the chemical composition of the milk (mainly content of casein, fat and (a) and coagulation properties. The highest $(p \leq 0.01)$ cheese yield was obtained from the milk of Polish Red cows (18.91 kg/100 kg; Table 1). For the White-backed and Simmental breeds, the estimated cheese yield was similar, 16.81 and $16.61 \mathrm{~kg} / 100 \mathrm{~kg}$, respectively. Irrespective of the cow breed, the estimated amount of cheese was higher in the autumn/winter than the spring/summer season (RP $11.4 \%$, SM $8.1 \%$, WB $6.1 \%$ ), which was linked to the higher content of dry matter constituents in the milk.
Table 3 shows the content of minerals in the milk. There were no statistically significant differences in the content of $\mathrm{Ca}, \mathrm{Na}, \mathrm{Mn}, \mathrm{Cu}$ or $\mathrm{Co}$ in the milk among cow breeds. The highest content of macronutrients, i.e. Ca (1470.85 mg/L) and $\mathrm{Na}(432.07 \mathrm{mg} / \mathrm{L})$, was found in the milk of Polish Red cows, and the highest levels of micronutrients, Mn (58.61 $\mu \mathrm{g} / \mathrm{L}), \mathrm{Cu}$ $(140.54 \mu \mathrm{g} / \mathrm{L})$ and Co $(2.36 \mu \mathrm{g} / \mathrm{L})$, in the milk of Simmentals. There were statistically significant $(p \leq 0.01)$ differences in the content of $\mathrm{K}, \mathrm{Mg}$ and $\mathrm{Zn}$ in the milk. The milk of White-backed and Polish Red cows had significantly $(p \leq 0.01)$ higher concentrations of $K$ and $\mathrm{Mg}$ than that of the Simmental breed. The greatest $(p \leq 0.01)$ Zn content was found in the milk of Whitebacked cows $-4.39 \mathrm{mg} / \mathrm{L}$. The lowest $\mathrm{Ni}$ content was found in the milk of Polish Red cows - 54.23 $\mu \mathrm{g} / \mathrm{L}(\mathrm{p} \leq 0.05)$. The content of macronutrients in the milk of Simmental cows was close to that reported by Manuelian et al. (2018b) for Italian Simmentals. It contained $1359.1 \mathrm{mg} / \mathrm{L} \mathrm{Ca}, 1501.7 \mathrm{mg} / \mathrm{L} \mathrm{K}$ and $429.4 \mathrm{mg} / \mathrm{L} \mathrm{Na}$. The mineral content in milk of native cow breeds was similar to the values obtained by Litwińczuk et al. (2018).

TABLE 3. The content of macro- and micronutrients in milk obtained from cows of local breeds in relation to the production season $(\overline{\mathrm{x}} \pm \mathrm{SD})$

\begin{tabular}{|c|c|c|c|c|c|c|c|c|c|}
\hline \multirow{2}{*}{$\begin{array}{l}\text { Breed } \\
\text { Season }\end{array}$} & \multicolumn{3}{|c|}{ White-backed } & \multicolumn{3}{|c|}{ Polish Red } & \multicolumn{3}{|c|}{ Simmental } \\
\hline & $\begin{array}{l}\text { Spring/ } \\
\text { summer }\end{array}$ & $\begin{array}{l}\text { Autumn/ } \\
\text { winter }\end{array}$ & $\begin{array}{l}\text { Overall mean } \\
\text { for breed }\end{array}$ & $\begin{array}{l}\text { Spring/ } \\
\text { summer }\end{array}$ & $\begin{array}{l}\text { Autumn/ } \\
\text { winter }\end{array}$ & $\begin{array}{l}\text { Overall mean } \\
\text { for breed }\end{array}$ & $\begin{array}{l}\text { Spring/ } \\
\text { summer }\end{array}$ & $\begin{array}{l}\text { Autumn/ } \\
\text { winter }\end{array}$ & $\begin{array}{l}\text { Overall mean } \\
\text { for breed }\end{array}$ \\
\hline $\mathrm{K}(\mathrm{mg} / \mathrm{L})$ & $\begin{array}{l}1560.59 \\
\pm 221.08\end{array}$ & $\begin{array}{l}1692.48 \\
\pm 287.52\end{array}$ & $\begin{array}{l}1628.89^{r} \\
\pm 263.84\end{array}$ & $\begin{array}{l}1695.93 \\
\pm 165.65\end{array}$ & $\begin{array}{l}1640.80 \\
\pm 168.34\end{array}$ & $\begin{array}{l}1669.66^{Y} \\
\pm 167.28\end{array}$ & $\begin{array}{l}1572.90^{A} \\
\pm 161.92\end{array}$ & $\begin{array}{l}1428.50^{\mathrm{B}} \\
\pm 190.10\end{array}$ & $\begin{array}{l}1506.59^{x} \\
\pm 191.14\end{array}$ \\
\hline $\mathrm{Ca}(\mathrm{mg} / \mathrm{L})$ & $\begin{array}{l}1376.89 \\
\pm 131.86\end{array}$ & $\begin{array}{l}1453.69 \\
\pm 215.70\end{array}$ & $\begin{array}{l}1416.66 \\
\pm 182.77\end{array}$ & $\begin{array}{l}1555.14^{b} \\
\pm 224.67\end{array}$ & $\begin{array}{l}1379.90^{a} \\
\pm 213.94\end{array}$ & $\begin{array}{l}1470.85 \\
\pm 230.56\end{array}$ & $\begin{array}{l}1343.50^{a} \\
\pm 142.16\end{array}$ & $\begin{array}{l}1442.75^{b} \\
\pm 173.29\end{array}$ & $\begin{array}{l}1400.76 \\
\pm 166.88\end{array}$ \\
\hline $\mathrm{Na}(\mathrm{mg} / \mathrm{L})$ & $\begin{array}{r}400.91 \\
\pm 81.84\end{array}$ & $\begin{array}{l}379.84 \\
\pm 106.54\end{array}$ & $\begin{array}{l}390.00 \\
\pm 95.17\end{array}$ & $\begin{array}{l}427.72 \\
\pm 63.91\end{array}$ & $\begin{array}{l}434.33 \\
\pm 76.64\end{array}$ & $\begin{array}{l}432.07 \\
\pm 71.73\end{array}$ & $\begin{array}{l}360.40^{A} \\
\pm 82.40\end{array}$ & $\begin{array}{l}452.22^{B} \\
\pm 172.62\end{array}$ & $\begin{array}{l}403.95 \\
\pm 147.93\end{array}$ \\
\hline $\mathrm{Mg}(\mathrm{mg} / \mathrm{L})$ & $\begin{array}{l}100.56 \\
\pm 12.23\end{array}$ & $\begin{array}{l}101.89 \\
\pm 13.03\end{array}$ & $\begin{array}{l}101.25^{Y} \\
\pm 12.56\end{array}$ & $\begin{array}{l}112.74 \\
\pm 9.75\end{array}$ & $\begin{array}{l}101.42 \\
\pm 20.65\end{array}$ & $\begin{array}{l}105.29^{Y} \\
\pm 18.36\end{array}$ & $\begin{array}{l}93.69 \\
\pm 9.83\end{array}$ & $\begin{array}{l}93.63 \\
\pm 12.66\end{array}$ & $\begin{array}{l}93.66^{x} \\
\pm 11.44\end{array}$ \\
\hline Zn (mg/L) & $\begin{array}{l}4.22 \\
\pm 1.12 \\
\end{array}$ & $\begin{array}{l}4.54 \\
\pm 1.29 \\
\end{array}$ & $\begin{array}{l}4.39^{\gamma} \\
\pm 1.10 \\
\end{array}$ & $\begin{array}{l}4.23 \\
\pm 0.93\end{array}$ & $\begin{array}{l}3.51 \\
\pm 1.15\end{array}$ & $\begin{array}{l}3.76^{x} \\
\pm 1.12 \\
\end{array}$ & $\begin{array}{l}3.94 \\
\pm 1.29\end{array}$ & $\begin{array}{l}3.51 \\
\pm 1.37 \\
\end{array}$ & $\begin{array}{l}3.70^{x} \\
\pm 1.34\end{array}$ \\
\hline $\mathrm{Fe}(\mathrm{mg} / \mathrm{L})$ & $\begin{array}{l}0.56 \\
\pm 0.18\end{array}$ & $\begin{array}{l}0.59 \\
\pm 0.18\end{array}$ & $\begin{array}{l}0.57^{y} \\
\pm 0.18\end{array}$ & $\begin{array}{l}0.59^{b} \\
\pm 0.16\end{array}$ & $\begin{array}{l}0.48^{a} \\
\pm 0.15\end{array}$ & $\begin{array}{l}0.52^{x y} \\
\pm 0.16\end{array}$ & $\begin{array}{l}0.51 \\
\pm 0.21\end{array}$ & $\begin{array}{l}0.48 \\
\pm 0.16\end{array}$ & $\begin{array}{l}0.49^{x} \\
\pm 0.18\end{array}$ \\
\hline $\mathrm{Mn}(\mu \mathrm{g} / \mathrm{L})$ & $\begin{array}{l}44.79^{A} \\
\pm 19.09\end{array}$ & $\begin{array}{l}71.23^{B} \\
\pm 18.93\end{array}$ & $\begin{array}{l}56.29 \\
\pm 22.91\end{array}$ & $\begin{array}{l}54.00 \\
\pm 16.53\end{array}$ & $\begin{array}{l}42.88 \\
\pm 11.78\end{array}$ & $\begin{array}{l}48.44 \\
\pm 15.16 \\
\end{array}$ & $\begin{array}{l}52.20 \\
\pm 14.12 \\
\end{array}$ & $\begin{array}{l}66.10 \\
\pm 23.12\end{array}$ & $\begin{array}{l}58.61 \\
\pm 19.72 \\
\end{array}$ \\
\hline $\mathrm{Cu}(\mu \mathrm{g} / \mathrm{L})$ & $\begin{array}{l}131.20 \\
\pm 48.11\end{array}$ & $\begin{array}{l}114.71 \\
\pm 43.62 \\
\end{array}$ & $\begin{array}{l}123.28 \\
\pm 45.82 \\
\end{array}$ & $\begin{array}{l}131.88^{b} \\
\pm 30.52\end{array}$ & $\begin{array}{l}109.18^{a} \\
\pm 13.06\end{array}$ & $\begin{array}{l}120.53 \\
\pm 25.75\end{array}$ & $\begin{array}{l}128.22 \\
\pm 38.00\end{array}$ & $\begin{array}{r}153.81 \\
\pm 37.44\end{array}$ & $\begin{array}{l}140.54 \\
\pm 39.23\end{array}$ \\
\hline Co $(\mu \mathrm{g} / \mathrm{L})$ & $\begin{array}{l}2.15 \\
\pm 0.62\end{array}$ & $\begin{array}{l}2.20 \\
\pm 0.90\end{array}$ & $\begin{array}{l}2.17 \\
\pm 0.75\end{array}$ & $\begin{array}{l}2.56^{b} \\
\pm 0.46\end{array}$ & $\begin{array}{l}2.11^{a} \\
\pm 0.40\end{array}$ & $\begin{array}{l}2.34 \\
\pm 0.48\end{array}$ & $\begin{array}{l}2.29 \\
\pm 0.51\end{array}$ & $\begin{array}{l}2.42 \\
\pm 0.55\end{array}$ & $\begin{array}{l}2.36 \\
\pm 0.52\end{array}$ \\
\hline $\mathrm{Ni}(\mu \mathrm{g} / \mathrm{L})$ & $\begin{array}{l}56.60 \\
\pm 9.81\end{array}$ & $\begin{array}{l}65.92 \\
\pm 13.96\end{array}$ & $\begin{array}{l}61.08^{y} \\
\pm 12.65\end{array}$ & $\begin{array}{l}54.94 \\
\pm 5.63\end{array}$ & $\begin{array}{l}53.52 \\
\pm 9.80\end{array}$ & $\begin{array}{l}54.23^{x} \\
\pm 7.86\end{array}$ & $\begin{array}{l}67.65^{\mathrm{b}} \\
\pm 11.93\end{array}$ & $\begin{array}{l}57.85^{\mathrm{a}} \\
\pm 5.56\end{array}$ & $\begin{array}{l}62.93^{y} \\
\pm 10.50\end{array}$ \\
\hline
\end{tabular}

a, $b$ - significant differences between seasons within a breed at $p \leq 0.05 ; A, B$ - significant differences at $p \leq 0.01$

$X, y$ - significant differences between breeds at $p \leq 0.05 ; X, Y$ - significant differences at $p \leq 0.01$ 
TABLE 4. Pearson correlation coefficients between the content of minerals and dry matter components and the coagulation properties of the milk

\begin{tabular}{l|l|l|l|l|l|l|l|l|l|l}
\hline & $\begin{array}{l}\mathrm{K} \\
(\mathrm{mg} / \mathrm{L})\end{array}$ & $\begin{array}{l}\mathrm{Ca} \\
(\mathrm{mg} / \mathrm{L})\end{array}$ & $\begin{array}{l}\mathrm{Na} \\
(\mathrm{mg} / \mathrm{L})\end{array}$ & $\begin{array}{l}\mathrm{Mg} \\
(\mathrm{mg} / \mathrm{L})\end{array}$ & $\begin{array}{l}\mathrm{Zn} \\
(\mathrm{mg} / \mathrm{L})\end{array}$ & $\begin{array}{l}\mathrm{Fe} \\
(\mathrm{mg} / \mathrm{L})\end{array}$ & $\begin{array}{l}\mathrm{Mn} \\
(\mu \mathrm{g} / \mathrm{L})\end{array}$ & $\begin{array}{l}\mathrm{Cu} \\
(\mu \mathrm{g} / \mathrm{L})\end{array}$ & $\begin{array}{l}\mathrm{Co} \\
(\mu \mathrm{g} / \mathrm{L})\end{array}$ & $\begin{array}{l}\mathrm{Ni} \\
(\mu \mathrm{g} / \mathrm{L})\end{array}$ \\
\hline Fat $(\mathrm{g} / 100 \mathrm{~g})$ & -0.114 & $0.202^{*}$ & 0.052 & $0.157^{*}$ & 0.034 & -0.005 & -0.020 & $0.227^{*}$ & 0.185 & 0.142 \\
\hline Protein $(\mathrm{g} / 100 \mathrm{~g})$ & -0.162 & $0.389^{* * *}$ & 0.041 & $0.351^{* * *}$ & $0.169^{*}$ & 0.066 & 0.080 & 0.204 & $0.437^{* * *}$ & $0.274^{*}$ \\
\hline Casein (g/100 g) & -0.090 & $0.306^{* * *}$ & 0.040 & $0.367^{* * *}$ & 0.144 & 0.077 & 0.135 & 0.069 & $0.323^{* *}$ & $0.231^{*}$ \\
\hline Lactose (g/100 g) & $0.226^{* *}$ & 0.029 & $-0.581^{* * *}$ & 0.003 & 0.055 & -0.109 & -0.206 & $-0.229^{*}$ & -0.163 & -0.167 \\
\hline $\begin{array}{l}\text { Dry matter } \\
\text { (g/100 g) }\end{array}$ & -0.092 & $0.299^{* * *}$ & -0.081 & $0.246^{* *}$ & 0.099 & -0.005 & -0.033 & 0.199 & $0.162^{*}$ & 0.170 \\
\hline RCT (min) & 0.003 & $-0.284^{* *}$ & 0.054 & -0.044 & $-0.164^{*}$ & -0.008 & 0.030 & $-0.263^{*}$ & $-0.309^{* *}$ & 0.020 \\
\hline $\mathrm{A}_{30}(\mathrm{~mm})$ & -0.001 & $0.301^{* * *}$ & -0.074 & $0.295^{* * *}$ & $0.173^{*}$ & 0.149 & -0.170 & 0.107 & $0.391^{* *}$ & 0.045 \\
\hline $\mathrm{K}_{20}(\mathrm{~min})$ & -0.125 & $-0.275^{* *}$ & 0.075 & $-0.358^{* * *}$ & -0.146 & -0.122 & 0.087 & 0.021 & $-0.327^{*}$ & -0.079 \\
\hline $\begin{array}{l}\text { Cheese yeild } \\
(\mathrm{kg} / 100 \mathrm{~kg})\end{array}$ & -0.114 & $0.202^{*}$ & 0.052 & 0.157 & 0.034 & -0.005 & -0.020 & $0.227^{*}$ & 0.185 & 0.142 \\
\hline
\end{tabular}

$\mathrm{RCT}$ - rennet coagulation time; $\mathrm{A}_{30}$ - curd firmness 30 min after rennet addition; $\mathrm{K}_{20}$ - curd-firming time;

${ }^{*} p \leq 0.05 ;{ }^{* *} p \leq 0.01 ;{ }^{* * *} p \leq 0.001$

TABLE 5. Percentage of RDA (recommended dietary allowance) for Ca and Mg for selected population groups covered by the consumption of $250 \mathrm{~mL}$ of milk from different cow breeds

\begin{tabular}{|c|c|c|c|c|c|c|c|c|c|c|c|}
\hline \multirow[t]{2}{*}{ Mineral } & \multirow{2}{*}{$\begin{array}{l}\text { Group } \\
\text { (Years old) }\end{array}$} & \multirow{2}{*}{$\begin{array}{l}\text { RDA } \\
\mathrm{mg} / \text { day }\end{array}$} & \multicolumn{3}{|c|}{ White-backed } & \multicolumn{3}{|c|}{ Polish Red } & \multicolumn{3}{|c|}{ Simmental } \\
\hline & & & I & II & mean & I & II & mean & I & II & mean \\
\hline \multirow[t]{15}{*}{$\mathrm{Ca}$} & \multicolumn{11}{|l|}{ Children } \\
\hline & $1-3$ & 700 & 49.2 & 51.9 & 50.6 & 55.5 & 49.3 & 52.5 & 48.0 & 51.5 & 50.0 \\
\hline & $4-9$ & 1000 & 34.4 & 36.3 & 35.4 & 38.9 & 34.5 & 36.8 & 33.6 & 36.1 & 35.0 \\
\hline & \multicolumn{11}{|l|}{ Boys } \\
\hline & $10-12$ & 1300 & 26.5 & 28.0 & 27.2 & 29.9 & 26.5 & 28.3 & 25.8 & 27.7 & 26.9 \\
\hline & $13-18$ & 1300 & 26.5 & 28.0 & 27.2 & 29.9 & 26.5 & 28.3 & 25.8 & 27.7 & 26.9 \\
\hline & \multicolumn{11}{|l|}{ Girls } \\
\hline & $10-12$ & 1300 & 26.5 & 28.0 & 27.2 & 29.9 & 26.5 & 28.3 & 25.8 & 27.7 & 26.9 \\
\hline & $13-18$ & 1300 & 26.5 & 28.0 & 27.2 & 29.9 & 26.5 & 28.3 & 25.8 & 27.7 & 26.9 \\
\hline & \multicolumn{11}{|l|}{ Men } \\
\hline & $19-65$ & 1000 & 34.4 & 36.3 & 35.4 & 38.9 & 34.5 & 36.8 & 33.6 & 36.1 & 35.0 \\
\hline & over 65 & 1200 & 28.7 & 30.3 & 29.5 & 32.4 & 28.7 & 30.6 & 28.0 & 30.1 & 29.2 \\
\hline & \multicolumn{11}{|l|}{ Women } \\
\hline & $19-50$ & 1000 & 34.4 & 36.3 & 35.4 & 38.9 & 34.5 & 36.8 & 33.6 & 36.1 & 35.0 \\
\hline & over 50 & 1200 & 28.7 & 30.3 & 29.5 & 32.4 & 28.7 & 30.6 & 28.0 & 30.1 & 29.2 \\
\hline \multirow[t]{15}{*}{$\mathrm{Mg}$} & \multicolumn{11}{|l|}{ Children } \\
\hline & $1-3$ & 80 & 31.43 & 31.84 & 31.64 & 35.23 & 31.69 & 32.90 & 29.28 & 29.26 & 29.27 \\
\hline & $4-9$ & 130 & 19.34 & 19.59 & 19.47 & 21.68 & 19.50 & 20.25 & 18.02 & 18.01 & 18.01 \\
\hline & \multicolumn{10}{|l|}{ Boys } & \\
\hline & $10-12$ & 240 & 10.48 & 10.61 & 10.55 & 11.74 & 10.56 & 10.97 & 9.76 & 9.75 & 9.76 \\
\hline & $13-18$ & 410 & 6.13 & 6.21 & 6.17 & 6.87 & 6.18 & 6.42 & 5.71 & 5.71 & 5.71 \\
\hline & \multicolumn{11}{|l|}{ Girls } \\
\hline & $10-12$ & 240 & 10.48 & 10.61 & 10.55 & 11.74 & 10.56 & 10.97 & 9.76 & 9.75 & 9.76 \\
\hline & $13-18$ & 360 & 6.98 & 7.08 & 7.03 & 7.83 & 7.04 & 7.31 & 6.51 & 6.50 & 6.50 \\
\hline & \multicolumn{11}{|l|}{ Men } \\
\hline & $19-65$ & 420 & 5.99 & 6.06 & 6.03 & 6.71 & 6.04 & 6.27 & 5.58 & 5.57 & 5.58 \\
\hline & over 65 & 420 & 5.99 & 6.06 & 6.03 & 6.71 & 6.04 & 6.27 & 5.58 & 5.57 & 5.58 \\
\hline & \multicolumn{11}{|l|}{ Women } \\
\hline & $19-30$ & 310 & 8.11 & 8.22 & 8.17 & 9.09 & 8.18 & 8.49 & 7.56 & 7.55 & 7.55 \\
\hline & over 30 & 320 & 7.86 & 7.96 & 7.91 & 8.81 & 7.92 & 8.23 & 7.32 & 7.31 & 7.32 \\
\hline
\end{tabular}

RDA - Recommended Dietary Allowance, I - spring/summer, II - autumn/winter 
The production season had a minor effect on the content of macro- and micronutrients in the milk (Table 4). In the case of White-backed cows, a statistically significant $(p \leq 0.01)$ difference was found only for the content of $\mathrm{Mn}$, which was nearly twice as high in the autumn/winter season (71.23 vs. $44.79 \mu \mathrm{g} / \mathrm{L}$ ) than in the spring/summer. Polish Red cows produced milk with higher $(p \leq 0.05)$ content of $\mathrm{Ca}, \mathrm{Fe}, \mathrm{Cu}$ and $\mathrm{Co}$ in the spring/summer period, i.e. $175.24 \mathrm{mg} / \mathrm{L}, 0.11 \mu \mathrm{g} / \mathrm{L}, 22.7 \mu \mathrm{g} / \mathrm{L}$ and $0.45 \mu \mathrm{g} / \mathrm{L}$, respectively, than in autumn/winter. In the milk of Simmental cows, significant seasonal differences were found for $\mathrm{K}$ and $\mathrm{Na}(\mathrm{p} \leq 0.01)$ and for $\mathrm{Ca}$ and $\mathrm{Ni}$ $(p \leq 0.05)$. The raw milk obtained in the spring/summer season had higher content of $\mathrm{K}$ and $\mathrm{Ni}$, while $\mathrm{Ca}$ and $\mathrm{Na}$ content were higher in autumn/winter. Analysis of the simultaneous influence of breed and season revealed significant interactions for $\mathrm{K}, \mathrm{Ca}$, $\mathrm{Ni}(\mathrm{p} \leq 0.01)$ and for $\mathrm{Zn}, \mathrm{Mg}, \mathrm{Na}, \mathrm{Cu}$ and $\mathrm{Mn}(\mathrm{p} \leq 0.05$; Table 2).

The impact of pasture feeding on mineral content in milk is not clear. Król et al. (2010a) have shown that raw milk obtained from Simmental cows raised in a traditional than in an intensive system to be richer in $\mathrm{Ca}$ and $\mathrm{Mg}$. On the other hand, milk from cows of this breed kept in an intensive system contained more $\mathrm{K}$ and $\mathrm{Na}$. The authors noted the highest $\mathrm{Ca}$ content in the milk of cows during the grazing period (1195.2 mg/L), while milk obtained in the winter contained over $220 \mathrm{mg} / \mathrm{L}$ less Ca. The high Ca content in milk obtained in the summer may have been due to its high content in pasture forage, which is the basis of the diet in traditional cow farming. In the period from spring to autumn, feeding is based on grasslands, both permanent and temporary, which are also the least expensive source of feed (Sobotka et al., 2011). Gabryszuk et al. (2008), in their assessment of the level of minerals in milk produced on conventional and organic farms, showed higher levels of $\mathrm{Ca}$ and $\mathrm{Mg}$ in milk from conventional farms when animals did not graze in the pasture. According to Toledo et al. (2002), milk obtained on conventional farms with intensive feeding may be a more valuable source of minerals than organic milk. Cows fed in an intensive system (TMR or PMR) receive a complete feed ration.

Table 4 shows the highest positive correlation coefficients between the content of $\mathrm{Ca}$ and protein $(r=0.389 ; p \leq 0,001)$, casein $(r=0.306 ; p \leq 0.001)$ and dry matter ( $r=0.299 ; p \leq 0.001)$, as well as between $\mathrm{Mg}$ and protein ( $r=0.351, \mathrm{p} \leq 0.001)$ and $\mathrm{Mg}$ and casein $(r=0.367, p \leq 0.01)$. A significant positive correlation was also found between Co and protein ( $r$ $=0.437, p \leq 0.01$ ). In addition, there was a negative relationship between $\mathrm{Na}$ and lactose concentration $(r=0.581, p \leq 0.001)$.

These relationships are supported by the results of several other studies. Nogalska et al. (2018) analysed the milk of Holstein-Friesian cows and showed a significant $(p \leq 0.01)$ positive correlations between the content of $\mathrm{Ca}$ and protein $(r=0.21)$ and $\mathrm{Ca}$ and dry matter $(r=0.48)$. Similarly, $\mathrm{Mg}$ content was positively correlated with the protein and the dry matter content (respectively $r=0.25$, $r=0.28, p \leq 0.01$ ). The authors also showed a negative correlation between lactose and $\mathrm{Na}$ content $(r=$ -0.32, $p \leq 0.01$ ). Similarly, Manuelian et al. (2018b) showed correlations between the content of minerals and the chemical composition of milk. The content of Ca and $\mathrm{Mg}$ was correlated with the level of fat ( $r=0.36, r=0.20$, respectively) and casein $(r=0.37, r=0.22$, respectively). The authors also confirmed a negative correlation for the content of $\mathrm{Na}$ and lactose $(r=-0.32)$.

The minerals in milk are associated not only with its nutritional value, but also with its coagulation properties. Colloidal fractions of $\mathrm{Ca}, \mathrm{P}$ and $\mathrm{Mg}$ are essential components of casein micelles, affecting their structure and functionality, and consequently the coagulation properties of milk (Petrera et al., 2016). A highly significant correlation coefficients were shown for $\mathrm{Ca}$ and $\mathrm{Mg}$ content and milk coagulation parameters. Ca content was correlated negatively with rennet clotting time and curd firming time $(r=-0.284, r=-0.275, p \leq 0.01$, respectively), but positively with curd firmness ( $r=0.301$, $p \leq 0.001)$ and cheese yield $(r=0.202, p \leq 0.05)$. The content of $\mathrm{Mg}$ was found to be positively correlated with curd firmness and curd firming time ( $r=0.295$, $r=0.358$, respectively, $p \leq 0.001)$. Similar relationships were obtained by Manuelian et al. (2018a), who showed that $\mathrm{Ca}$ and $\mathrm{Mg}$ content were negatively correlated with clotting time $(r=-0.30, r=$ -0.20 , respectively) and curd firming time ( $r=-0.45$, $r=-0.30$ ). The content of these minerals in the milk was also positively correlated with the firmness of the curd $(r=0.36, r=0.14)$. 
Milk and dairy products are an excellent source of $\mathrm{Ca}$ in the human diet. Ca performs a number of functions, including the regulation of the sensitivity of nerve cells. Clinical studies have shown that adequate $\mathrm{Ca}$ intake that satisfies daily requirements lowers blood pressure, reduces the risk of hypertension, and has anti-cancer effects (Jacqmain et al., 2003). Mg also plays an important role in physiological processes, preventing hypertension, atherosclerosis, kidney disease and osteoporosis. The Food and Nutrition Institute in Warsaw recommends at least two glasses of milk or dairy products a day for adults and 3-4 servings for children and adolescents.

Table 5 shows the percentage of the recommended daily allowance (RDA) of $\mathrm{Mg}$ and Ca calculated for $250 \mathrm{~mL}$ of milk. The results indicate a higher percentage of the RDA for $\mathrm{Ca}$ than for $\mathrm{Mg}$ in the milk. The highest percentage of the daily allowance for $\mathrm{Ca}$ and $\mathrm{Mg}$ was obtained for the milk of Polish Red cows in the spring/summer season (diet based mainly on pasture grazing) for all groups. The milk of the White-backed and Simmental cows obtained in the autumn/winter period contained a higher percentage of the RDA for Ca than milk from spring/summer.

Consumption of $250 \mathrm{~mL}$ of milk can meet the daily requirement for $\mathrm{Ca}$ and $\mathrm{Mg}$, especially in children. A $250 \mathrm{~mL}$ portion of milk may constitute as much as $48-55.5 \%$ of the RDA for Ca for younger children (1-3 years) and 33.6-38.9\% of the RDA for older children (4-9 years). For Mg, the corresponding ranges were $29.26-35.23 \%$ and $18.01-21.68 \%$ of the RDA. Due to the higher requirement for Ca in boys and girls ( $1300 \mathrm{mg} / \mathrm{d})$, these values were lower and ranged from $25.8 \%$ to $29.9 \%$ of the RDA.

\section{Conclusions}

Summing up, the milk of local breeds raised in Poland is of high nutritional value and has good coagulation properties. The highest concentration of basic constituents and the best coagulation parameters were found in the milk of Polish Red cows. Due to the traditional feeding system, based mainly on pasture forage in the spring and summer and on silage or hay in autumn and winter, the milk contains more dry matter in the latter period. The raw milk obtained in the pasture season had more favourable coagulation properties. The content of minerals in the milk, however, was not clearly determined by the breed or the season. It probably results from the content of minerals in feed, and this in turn from their content in the soil and the level of fertilization. The milk of Polish Red cows fed mainly on pasture forage had a more favourable nutritional profile, with the highest levels of $\mathrm{Ca}$ and $\mathrm{Mg}$ among all groups. A glass of this milk ( $250 \mathrm{~mL}$ ) can be a valuable source of $\mathrm{Ca}$ in the diet of children from 1 to 9 years of age, and can largely meet the recommended daily allowances for teenagers and adults. Additional information on the labels of dairy products indicating that they are produced from the milk of cows of local breeds could increase their marketability and thereby improve the economic efficiency of farms, and in the long term contribute to the maintenance of indigenous cattle breeds in Poland.

\section{Acknowledgements}

The work was carried out under the BIOSTRATEG project "Directions of use and conservation of genetic resources of livestock under sustainable development conditions", funded by the National Centre for Research and Development as part of the Strategic Research and Development Programme "Natural Environment, Agriculture and Forestry" (BIOSTRATEG2/297267/2/NCBR/2016). 


\section{Prehrambena vrijednost i sposobnost koagulacije kravljeg mlijeka lokalnih pasmina uključujući odabrane makro- i mikronutrijente te elemente u tragovima}

\section{Sažetak}

Cilj ovog istraživanja bio je odrediti prehrambenu vrijednost mlijeka na osnovu kemijskog sastava i sadržaja odabranih mineralnih tvari, te sposobnost koagulacije sirovog mlijeka izvornih pasmina - poljsko crvenih i bijelo-crnih, lokalno uzgojenih simentalskih krava, uzimajući u obzir utjecaj sezone. Istraživanje je provedeno na ukupno 418 uzoraka mlijeka uzetih tijekom proljeća/ljeta (travanj do rujan) odnosno jeseni/zime (listopad do ožujak). Uzorcima su određivani kemijski sastav, energijska vrijednost, sposobnost koagulacije (RCT - vrijeme zgrušavanja, $A_{30}$ - čvrstoća gruša, $K_{20}$ - vrijeme potrebno za postizanje odgovarajuće čvrstoće gruša), prinos sira te sadržaj K, Na, Ca, Mg, Zn, Fe, Mn, Cu, Ni i Co. Također je određeno u kojem postotku konzumacija 250 mL testiranih uzoraka mlijeka pokriva dnevni preporučeni unos Ca i Mg za djecu, adolescente i odrasle. Mlijeko pasmine poljsko crveno sadržavalo je najviše koncentracije osnovnih nutrijenata (1 kg mlijeka imalo je energijsku vrijednost od 823,98 kcal) i imalo je najbolju sposobnost koagulacije mlijeka (najkraće vrijeme zgrušavanja (16:09 min, ps0,01) i najčvršći gruš (30,74 mm)). Ovaj uzorak mlijeka imao je bolji nutritivni profil budući da je sadržavao najviši postotak preporučenih dnevnih unosa za Ca i Mg. Sirovo mlijeko dobiveno u sezoni ispaše imalo je bolje parametre sposobnosti koagulacije. Sadržaj mineralnih tvari nije bio uvjetovan pasminom ni sezonom proizvodnje. To je vjerojatno posljedica većih udjela ovih nutrijenata u stočnoj hrani, što je povezano s njihovim sadržajem u tlu kao i sa stupnjem fertiliziacije.

\section{Ključne riječi: lokalne pasmine, mineralne tvari, sezona, sposobnost koagulacije, prehrambena vrijednost}

\section{References}

1. AOAC International Casein Nitrogen Content of Milk. Official Methods of Analysis: (2000) 17th Ed., Gaithersburg, MD. Method Number: 998.06.

2. Barłowska, J., Litwińczuk, Z., Brodziak, A., Chabuz, W. (2012): Effect of the production season on nutritional value and technological suitability of milk obtained from intensive (TMR) and traditional feeding system of cows. Journal of Microbiology, Biotechnology and Food Sciences 1 (5), 1205-1220.

https://doi.org/10.2478/v10220-012-0036-0

3. Beux, S., Cassandro, M., Lima, V. A., Zielinski, A. A. F., Nogueira, A., Waszczynskyj, N. (2018): Seasonal effect on milk composition, somatic cell content and milk coagulation properties of Italian Holstein-Friesian cows. Emirates Journal of Food and Agriculture 30, 998-1005. https://doi.org/10.9755/ejfa.2018.v30.i12.1865

4. Bittante, G., Penasa, M., Cecchinato, A. (2012): Genetics and modeling of milk coagulation properties. Journal of Dairy Science 95, 6843-6870.

https://doi.org/10.3168/jds.2012-5507

5. Bittante, G., Cipolat-Gotet, C., Malchiodi, F., Sturaro, E., Tagliapietra, F., Schiavon, S., Cecchinato, A. (2015): Effect of dairy farming system, herd, season, parity, and days in milk on modeling of the coagulation, curd firming, and syneresis of bovine milk. Journal of Dairy Science 98, 2759-2774.

https://doi.org/10.3168/jds.2014-8909
6. Bohdanowicz-Zazula, M., Nowopolska-Szczyglewska, A., Synowiec, M., Pawelska, M. (2003): Variability of composition and technological parameters of milk of cows fed in the TMR system depending on the season of the year, lactation period and productivity level (in Polish). Zeszyty Naukowe Przeglacdu Hodowlanego 69, 197-204.

7. Brodziak, A., Barłowska, J., Król, J., Litwińczuk, Z. (2012): Effect of breed and feeding system on content of selected whey proteins in cow's milk in spring-summer and autumn-winter seasons. Annals of Animal Science 12, 261-269.

https://doi.org/10.2478/v10220-012-0022-6

8. Brodziak, A., Król, J., Litwińczuk, Z., Barłowska, J. (2018): Differences in bioactive protein and vitamin status of milk from certified organic and conventional farms. International Journal of Dairy Technology 71(2), 321-332. https://doi.org/10.1111/1471-0307.12462

9. Chládek, G., Čejna, V., Falta, D., Máchal, L. (2011): Effect of season and herd on rennet coagulation time and other parameters of milk technological quality in holstein dairy cows. Acta Universitatis Agriculturae et Silviculturae Mendelianae Brunensis 59 (5), 113-118. https://doi.org/10.11118/actaun201159050113

10. Commission Regulation (EC) No 1662/2006 of 6 November 2006 amending Regulation (EC) No 853/2004 of the European Parliament and of the Council laying down specific hygiene rules for food of animal origin. 
11. Dell Inc. (2016): Dell Statistica (data analysis software system), version 13. software.dell.com.

12. Espinoza, J. L., Sánchez, J., Gracia, J. A., Sánchez, J. R., Ortega, R., Palacios, A. (2009): Thermoregulation differs in Chinampo (Bos taurus) and locally born dairy cattle. Turkish Journal Of Veterinary And Animal Sciences 33, 175180.

13. Gabryszuk, M., Słoniewski, K., Sakowski, T. (2008): Macro- and microelements in milk and hair of cows from conventional vs. organic farms. Animal Science Papers and Reports 26 (3), 199-209.

14. Gandini, G., Maltecca, C., Pizzi, F., Bagnato, A., Rizzi, R. (2007): Comparing local and commercial breeds on functional traits and profitability: The case of Reggiana dairy cattle. Journal of Dairy Science 90, 2004-2011. https://doi.org/10.3168/jds.2006-204

15. Halagarda, M., Ptasińska-Marcinkiewicz, J., Fijoreka, K. (2018): Comparison of mineral elements content in conventional and organic milk from southern Poland. Żywność. Nauka. Technologia. Jakość 25 (1), 137-150.

16. Jacqmain, M., Doucet, E., Després, J.P., Bouchard, C., Tremblay, A. (2003): Calcium intake, body composition, and lipoprotein-lipid concentrations in adults. Ammerican Journal of Clinical Nutrition 77, 1448-1452. https://doi.org/10.1093/ajcn/77.6.1448

17. Król, J., Brodziak, A., Wolanciuk, A., Wójcik, M. (2010a): Elements' content in milk of Simmental cows depending on feeding system (in Polish). Roczniki Naukowe Polskiego Towarzystwa Zootechnicznego 6 (4), 321-328. https://doi.org/10.5604/01.3001.0013.5306

18. Król, J., Litwińczuk, Z., Brodziak, A., Sawicka-Zugaj, W. (2010b): Bioactive protein content in milk from local breeds of cows included in the genetic resources conservation programme. Annals of Animal Science 10 (3), 213-221. https://doi.org/10.2478/v10220-012-0036-0

19. Kubarsepp, I., Henno, M., Viinalass, H., Sabre, D. (2005): Effect of $\mathrm{k}$-casein and $\beta$-lactoglobulin genotypes on the milk rennet coagulation properties. Agronomy Research 3 (1), 55-64.

20. Litwińczuk, Z., Barłowska, J., Chabuz, W., Brodziak, A. (2012): Nutritional value and technological suitability of milk from cows of three Polish breeds included in the genetic resources conservation programme. Annals of Animal Science 12 (3), 423-432.

https://doi.org/10.2478/v10220-012-0036-0

21. Litwińczuk, Z., Koperska, N., Chabuz, W., KędzierskaMatysek, M. (2018): Basic chemical composition and mineral content of the milk of cows of various breeds raised on organic farms and on traditional farms using intensive and traditional feeding systems (in Polish). Medycyna Weterynaryjna 74 (5), 309-313. https://doi.org/10.21521/mw.6022

22. Manuelian, C. L., Penasa, M., Visentin, G., Cassandro, M., De Marchi, M. (2018a): Phenotypic analysis of milk coagulation properties and mineral content of Pinzgauer cattle breed. Archives Animal Breeding 61, 215-220. https://doi.org/10.5194/aab-61-215-2018
23. Manuelian, C.L., Penasa, M., Visentin, G., Zidi, A., Cassandro, M., De Marchi, M. (2018b): Mineral composition of cow milk from multibreed herds. Animal Science Journal 89, 162-1627. https://doi.org/10.1111/asj.13095

24. Matwijczuk, A., Wójcik-Saganek, A., Barłowska, J. (2015): Basic chemical composition, casein content and energy value of the milk of cows of the Polish Red, WhiteBacked and Simmental breeds, taking into account their daily yield. Roczniki Naukowe Polskiego Towarzystwa Zootechnicznego 11 (1), 85-91. https://doi.org/10.5604/01.3001.0013.5418

25. Melilli, C., Lynch, J.M., Carpino, S., Barbano, D.M., Licitra, G., Cappa, A. (2002): An empirical method for prediction of cheese yield. Journal of Dairy Science 85, 2699-2704. https://doi.org/10.3168/jds.s0022-0302(02)74356-7

26. Miranda, J. E. C., Freitas, A. F. (2009): Raças e Tipos de Cruzamentos para Produção de Leite. Embrapa Gado de Leite. Circular Técnica 98, 1-12.

27. NFNI (2017): Nutritional standards for the Polish population. The National Food and Nutrition Institute in Warsaw. https://ncez.pl/upload/normy-net-1.pdf. (Accessed 29 July 2019).

28. Nogalska, A., Momot, M., Sobczuk-Szul, M., PogorzelskaPrzybyłek, P., Nogalski, Z. (2018): The effect of milk production performance of Polish Holstein-Friesian (PHF) cows on the mineral content of milk. Journal of Elementology 23 (2), 589-597. https://doi.org/10.5601/jelem.2017.22.4.1528

29. Petrera, F., Catillo, G., Napolitano, F., Malacarne, M., Franceschi, P., Summer, A., Abeni, F. (2016): New insights into the quality characteristics of milk from Modenese breed compared with Italian Friesian. Italian Journal of Animal Science 15 (4), 559-567. https://doi.org/10.1080/1828051x.2016.1222889

30. Pijanowski, E., Dłużewski, M., Dłużewska, A., Jarczyk, A. (2000): General food technology (in Polish). ed. Warszawa, Wydawnictwo Naukowo-Techniczne.

31. Radkowska, I., Radkowski, A. (2016): Effects of season and lactation stage on milk yield and its composition in pasture and TMR -fed Simmental cows (in Polish). Roczniki Naukowe Polskiego Towarzystwa Zootechnicznego 43 (4), 205-214. https://doi.org/10.5604/01.3001.0013.5418

32. Sobotka, W., Miciński, J., Wróblewski, P., Zwierzchowski, G. (2011): The effect of conventional and TMR feeding systems on feed intake, cow productivity, milk composition and hygienic quality (in Polish). Roczniki Naukowe Polskiego Towarzystwa Zootechnicznego 7 (4), 87-96. https://doi.org/10.5604/17337305

33. Toledo, P., Andren, A., Bjorck, L. (2002): Composition of raw milk from sustainable production systems. International Dairy Journal 12, 75-80. https://doi.org/10.1016/s0958-6946(01)00148-0

34. Zannoni, M., Annibaldi, S. (1981): Standardization of the renneting ability of milk by Formagraph. Scienza e Tecnica Lattiero-Casearia 32 (3), 79-94. 